\title{
CONTROL OF GLYPHOSATE-RESISTANT VOLUNTEER MAIZE USING ACCaSe INHIBITING HERBICIDES ${ }^{1}$
}

\author{
SAUL JORGE PINTO DE CARVALHO ${ }^{2 *}$, ELVIO LORENÇATO UZUELE ${ }^{3}$, DANIEL JORGE SOARES ${ }^{4}$, RAMIRO \\ FERNANDO LÓPEZ OVEJERO ${ }^{4}$, PEDRO JACOB CHRISTOFFOLETI ${ }^{5}$
}

\begin{abstract}
ABSTRAC - Controlling volunteer plants was aggravated due to the emergence of genetically modified glyphosate-resistant cultivars, requiring new technical recommendations. This work was developed with the objective of evaluating alternatives for chemical control of glyphosate-resistant maize infesting soybean crops, using ACCase inhibiting herbicides. Two experiments were carried out, one in Santa Cruz das Palmeiras (SP) and other in Não-Me-Toque (RS), Brazil. Volunteer maize plants were simulated with seeds of the DKB 390 YGRR2 hybrids, distributed between rows of soybean crops, at the density of 6 plants $\mathrm{m}^{-2}$. Combinations of the herbicides clethodim (65 and $84 \mathrm{~g} \mathrm{ha}^{-1}$ ), sethoxydim (138 and $165 \mathrm{~g} \mathrm{ha}^{-1}$ ), and haloxyfop (36 and $45 \mathrm{~g} \mathrm{ha}^{-1}$ ) were applied at two phenological stages of the soybean crop [three (3T) and six (6T) trifoliate leaves], corresponding to the V4/V5 and V7/V8 stages of the volunteer maize, respectively, resulting in 14 treatments. A treatment without herbicide application and a treatment with manual weeding were included as check plots. Applying graminicides on maize plants at V4/V5 stage resulted in more consistent results and general efficacy. Soybean yield was lower when applying herbicide only on maize plants at V7/V8, in both locations. Therefore, management practices for glyphosate-resistant volunteer maize should be adopted early, on maize plants at the V4/V5 stage, mainly when the maize plants are from lost grains in the harvesting process. The use of the herbicides clethodim and haloxyfop results in consistent control efficacy of volunteer maize plants.
\end{abstract}

Keywords: Glycine max. Graminicides. Management. Tolerance. Zea mays.

\section{CONTROLE DE MILHO VOLUNTÁRIO RESISTENTE AO GLYPHOSATE COM HERBICIDAS INIBIDORES DA ACCase}

RESUMO - O controle das plantas voluntárias foi dificultado com o advento das culturas geneticamente modificadas para tolerância ao herbicida glyphosate, exigindo novas recomendações técnicas para manejo. Este trabalho foi desenvolvido com o objetivo de avaliar alternativas para controle químico de plantas voluntárias de milho resistentes ao glyphosate, infestantes na cultura da soja, por meio de herbicidas graminicidas inibidores da ACCase. Dois experimentos foram desenvolvidos em campo, sendo um em Santa Cruz das Palmeiras (SP) e outro em Não-Me-Toque (RS). Para representar as plantas voluntárias de milho, sementes do híbrido DKB 390 YGRR2 foram distribuídos nas entrelinhas da soja, na densidade de 6 plantas $\mathrm{m}^{-2}$. Adotaram-se 14 tratamentos, resultantes da combinação dos herbicidas clethodim (65 e $\left.84 \mathrm{~g} \mathrm{ha}^{-1}\right)$, sethoxydim (138 e $\left.165 \mathrm{~g} \mathrm{ha}^{-1}\right)$ e haloxyfop (36 e $45 \mathrm{~g} \mathrm{ha}^{-1}$ ), com dois estádios fenológicos da cultura de soja (três (3T) e seis (6T) trifólios); estando as plantas de milho voluntário nos estádios V4/V5 e V7/V8, respectivamente. Foi adicionado um tratamento sem aplicação de herbicidas e uma testemunha capinada manualmente. A pulverização dos graminicidas sobre plantas de milho em V4/V5 promoveu melhor consistência dos resultados e eficácia geral. A produtividade da soja foi reduzida em ambas as localidades com as pulverizações realizadas somente em V7/V8. Assim sendo, medidas de controle do milho voluntário resistente ao glyphosate devem ser adotadas precocemente, sobretudo quando o milho for resultante de grãos perdidos no processo de colheita. Neste sentido, destaca-se a adoção dos herbicidas clethodim e haloxyfop por sua eficácia consistente.

Palavras-chave: Glycine max. Graminicidas. Manejo. Tolerância. Zea mays.

\footnotetext{
${ }^{*}$ Corresponding author

${ }^{1}$ Received for publication in 05/28/2017; accepted in 09/14/2018.

${ }^{2}$ Instituto Federal de Educação, Ciência e Tecnologia do Sul de Minas Gerais, Machado, MG, Brazil; saul.carvalho@ifsuldeminas.edu.br ORCID: 0000-0002-8558-6922.

${ }^{3}$ Monsanto do Brasil, Santa Cruz das Palmeiras, SP, Brazil; elvio_uzuele@icloud.com - ORCID: 0000-0002-5970-7671.

${ }^{4}$ Agro Bayer Brasil, Santa Cruz das Palmeiras, SP, Brazil; daniel.soares@bayer.com - ORCID: 0000-0002-1199-689X; ramiro.ovejero@bayer.com - ORCID: 0000-0003-4500-6302.

${ }^{5}$ Department of Crop Science, Universidade de São Paulo, Piracicaba, SP, Brazil; pjchrist@usp.br - ORCID: 0000-0002-2741-5615.
}

Rev. Caatinga, Mossoró, v. 32, n. 3, p. 575 - 580, jul. - set., 2019 


\section{INTRODUCTION}

Brazil is a world leader in grain production, including maize (Zea mays L.) and soybean (Glycine $\max$ (L.) Merril). According to the Brazilian National Supply Company (CONAB, 2018), in the 2016/2017 crop season, 33.9 million hectares of soybean were harvested, with an estimated production of 114 million $\mathrm{Mg}$; and 17.6 million hectares of maize were harvested, with a total production (first and second harvests) estimated in 97.8 million $\mathrm{Mg}$.

The land use intensification in current productive environments has been characterized by the adoption of crop succession or rotation systems. The most adopted crop succession in Brazil is soybean-maize, with soybean grown as first crop and maize as a second crop in succession, covering expressive production areas (ARTUZI; CONTIERO, 2006; PETTER et al., 2015; LÓPEZ-OVEJERO et al., 2016a). In the 2016/2017 crop season, maize production as second crop reached 67.4 million $\mathrm{Mg}$, representing an increase of $65.2 \%$ when compared to the previous crop season (2015/2016), which accounted for 40.8 million $\mathrm{Mg}$ (CONAB, 2018).

The soybean-maize succession has long been used in Brazil, with a high predominance in production systems. These crops are harvested mechanically in most areas, using harvesters of different efficiency levels, especially in those areas that use high technology. Thus, grain losses during the harvest always occur on a greater or lesser extent, and the grains left in the areas can infest subsequent crops (PUZZI, 1986; SOUZA et al., 2006). Therefore, the appearance of volunteer maize plants from grains of the previous crop in the subsequent crop is frequent, and they are responsible for losses due to weed competition (BECKETT; STOLLER, 1988; CHAHAL et al., 2014).

Loose grains or lost ears during the maize harvest can remain in the soil and present germination and emergence viability throughout the dry season (winter period). After the beginning of the rainy season and sowing of the subsequent crop, i.e., the first crop of the next crop season, these grains can establish as voluntary plants and, as well as weeds, they cause significant negative effects on crop yield due to the competition of the plants for water, light, and nutrient resources (LÓPEZOVEJERO et al., 2016a).

Volunteer maize plants in soybean crops compete for water, light, and nutrients, with emphasis on competition for light due to their greater size (MARQUARDT; KRUPKE; JOHNSON, 2012). In these conditions, soybean yield losses of up to $69.9 \%$ may occur, mainly when there is presence of ears, which provides successive and uneven germinations, making control measures difficult (LÓPEZ-OVEJERO et al., 2016a).

For a few years, glyphosate was an effective alternative for the control of volunteer maize in resistant soybean crops to this herbicide (RR soybean). However, after the technology of glyphosate-resistant maize, this possibility was not feasible, requiring the application of herbicides of other mechanisms of action, with emphasis on the ACCase inhibitor graminicides (DEEN et al., 2006; SOLTANI; SHORPSHIRE; SIKKEMA, 2006; STECKEL; THOMPSON; HAYES, 2009; MARCA et al., 2015). Thus, herbicide-resistant volunteer maize infestation is currently common in crops that are resistant to the same herbicides and sown in succession or rotation (THOMAS et al., 2007; CLEWIS et al., 2008; STECKEL; THOMPSON; HAYES, 2009; PETTER et al., 2015).

Considering the various options of graminicides available commercially in Brazil, as well as the agrometeorological diversity of the country, there is still a lack of information on control programs of glyphosate-resistant volunteer maize infesting soybean crops. Therefore, this work was developed with the objective of evaluating alternatives for the chemical control of glyphosateresistant volunteer maize plants, when germinated in the soybean crop, through applications of ACCase inhibitor graminicides.

\section{MATERIAL AND METHODS}

Two independent field experiments were carried out with soybean crops in the 2010/2011 crop season; one in Não-Me-Toque, RS (NMT) and other in Santa Cruz das Palmeiras, SP (SCP), Brazil. The soybean crops were grown in an area with total weed control through glyphosate applications at presowing and post-emergence of the crops. The soybean cultivars used were BMX Titan RR, with sowing on October 08, 2010 (SCP), and NA4990RG, with sowing on December 09, 2010 (NMT).

The crops were grown with spacing of $0.50 \mathrm{~m}$ between the soybean rows, under adequately soil fertilization and phytosanitary conditions. The experiments were performed in a randomized block design, with 14 treatments and four replications, totaling 56 plots in each experiment (Table 1). The experimental plots consisted of six 5-meter soybean rows, totaling $15 \mathrm{~m}^{2}$, with an evaluation area of $5 \mathrm{~m}^{2}$. The conditions of competition of soybean with glyphosate-resistant volunteer maize were simulated by manually distribution of maize seeds of the DKB390YGRR2 hybrid between rows of soybean crops, at the density of 6 plants $\mathrm{m}^{-2}$, during the soybean sowing.

The herbicides used as chemical treatments were clethodim (65 and $84 \mathrm{~g} \mathrm{ha}^{-1}$ ), sethoxydim (138 and $165 \mathrm{~g} \mathrm{ha}^{-1}$ ), and haloxyfop (36 and $\left.45 \mathrm{~g} \mathrm{ha}^{-1}\right)$. They were applied on soybean plants when they had three (3T) and six (6T) trifoliate leaves. A treatment without herbicide application and a treatment with 
manual weeding were included as check plots (Table 1). The herbicide rates were chosen considering the minimum and maximum recommendations described in the product labels. Maize plants at the V4/V5 and V7/V8 stages were found at the first and second herbicide applications, respectively.

The herbicides were applied using a $\mathrm{CO}_{2-}$ pressurized backpack sprayer coupled a bar with four
TT110.015 nozzles spaced $0.50 \mathrm{~m}$ apart, set to an application volume proportional to $120 \mathrm{~L} \mathrm{ha}^{-1}$. Mineral oil $\left(0.5 \% \mathrm{v} \mathrm{v}^{-1}\right)$ was added to all herbicides. The effect of the competition of volunteer maize with soybean was isolated by kept all soybean plots free from weed competition, using two glyphosate applications at $720 \mathrm{~g} \mathrm{ha}^{-1}$ at 14 and 28 days after the soybean sowing, apart to the treatments.

Table 1. Detail of the experimental treatments installed using different herbicides, in two application times, besides check plots without herbicide application and a fully weeded control.

\begin{tabular}{cccc}
\hline Treatment & Herbicide & Rate $\left(\mathrm{g}\right.$ a.i. ha $\left.{ }^{-1}\right)$ & ${\text { Application } \text { time }^{1}}^{-1}$ \\
\hline 1 & clethodim $^{2}$ & 65 & $3 \mathrm{~T}$ \\
2 & clethodim $^{2}$ & 84 & $3 \mathrm{~T}$ \\
3 & sethoxydim $^{3}$ & 138 & $3 \mathrm{~T}$ \\
4 & sethoxydim $^{4}$ & 165 & $3 \mathrm{~T}$ \\
5 & haloxyfop & $3 \mathrm{~T}$ \\
6 & haloxyfop & 36 & $3 \mathrm{~T}$ \\
7 & clethodim & 45 & $6 \mathrm{~T}$ \\
8 & clethodim & 65 & $6 \mathrm{~T}$ \\
9 & sethoxydim & 84 & $6 \mathrm{~T}$ \\
10 & sethoxydim & 138 & $6 \mathrm{~T}$ \\
11 & haloxyfop & 165 & $6 \mathrm{~T}$ \\
12 & haloxyfop & 36 & $6 \mathrm{~T}$ \\
13 & & 45 & \\
14 & & Check plots without herbicide application & \\
\hline
\end{tabular}

${ }^{1} 3 \mathrm{~T}=$ Soybean plants with 3 trifoliate leaves; $6 \mathrm{~T}=$ Soybean plants with 6 trifoliate leaves; ${ }^{2}$ Select $240 \mathrm{EC}$ $\left(240 \mathrm{~g}\right.$ of clethodim $\left.\mathrm{L}^{-1}\right) ;{ }^{3}$ Poast $\left(184 \mathrm{~g}\right.$ of sethoxydim $\left.\mathrm{L}^{-1}\right) ;{ }^{4}$ Verdict* $\mathrm{R}\left(120 \mathrm{~g}\right.$ of haloxyfop $\left.\mathrm{L}^{-1}\right)$.

The variables analyzed were: percentage of control of maize plants at 14, 21, and 28 days after application (DAA) of each herbicide, and soybean stand and yield $\left(\mathrm{kg} \mathrm{ha}^{-1}\right)$. The percentage of control was evaluated considering $0 \%$ as absence of control, and $100 \%$ as dead plants (SBCPD, 1995). The soybean crop stand was evaluated in the two central rows when the soybean plants were at phenological maturity, when the plants of the evaluation area of the plots were harvested. The soybean yield was evaluated by weighing the soybean grains, considering a grain moisture of $13 \%$.

All data were subjected to the F test in the analysis of variance, with a minimum of $5 \%$ of significance, considering the sites as independent experiments. Then, when the means were significant, the data were subjected to the Scott-Knott mean clustering test $(P \leq 0.05)$.

\section{RESULTS AND DISCUSSION}

The phenological stage of volunteer maize plants at the time of the herbicide applications was a determinant factor for the herbicide efficacy in both experimental areas (Table 2). The herbicide applications on maize plants at the V4/V5 stage showed more consistent results and general efficacy; clethodim at both used rates and haloxyfop at $45 \mathrm{~g}$ ha ${ }^{-1}$ achieved maximum control in all evaluations in both experiments. The use of haloxyfop at $36 \mathrm{~g} \mathrm{ha}^{-1}$ also resulted in satisfactory control of volunteer maize plants, above $80 \%$; however, this treatment was not similar to the best treatments at 14 days after application (DAA) of herbicides in the experiment of Santa Cruz das Palmeiras, SP (SCP) (Table 2).

In general, the herbicide efficacy was low when the herbicides were applied on maize plants at the V7/V8 stage (Table 2). No treatment reached efficacy higher than $80 \%$ in SCP when the herbicides were applied on maize plants at V7/V8, i.e., below the minimum control level for herbicides (FRANS et al., 1986). Control levels above $80 \%$ were found at 21 and 28 DAA in the experiment in Não-Me-Toque, RS (NMT), when applying clethodim $\left(84 \mathrm{~g} \mathrm{ha}^{-1}\right)$ and haloxyfop. However, these treatments had similar efficacy to the highest efficacy levels only at 28 DAA, with applications on volunteer maize plants at V4/V5 (Table 2). 
Table 2. Percentage of control of volunteer maize between soybean crop rows at 14, 21, and 28 days after herbicide applications on plants at the V4/V5 and V7/V8 stages.

\begin{tabular}{|c|c|c|c|c|c|c|c|}
\hline \multirow{2}{*}{$\begin{array}{l}\text { Treatments } \\
\left(\mathrm{g} \mathrm{ha}^{-1}\right)\end{array}$} & \multirow{2}{*}{ Maize phenological stage } & \multicolumn{3}{|c|}{$\mathrm{SCP}^{2}$} & \multicolumn{3}{|c|}{$\mathrm{NMT}^{3}$} \\
\hline & & 14 & 21 & 28 & 14 & 21 & 28 \\
\hline T1. Clethodim -65 & V4/V5 & $98.5 \mathrm{a}$ & $100.0 \mathrm{a}$ & $100.0 \mathrm{a}$ & $99.3 \mathrm{a}$ & $100.0 \mathrm{a}$ & $100.0 \mathrm{a}$ \\
\hline T2. Clethodim -84 & V4/V5 & $96.5 \mathrm{a}$ & $100.0 \mathrm{a}$ & $100.0 \mathrm{a}$ & $99.5 \mathrm{a}$ & $100.0 \mathrm{a}$ & $100.0 \mathrm{a}$ \\
\hline T3. Sethoxy dim - 138 & $\mathrm{~V} 4 / \mathrm{V} 5$ & $81.5 \mathrm{c}$ & $82.0 \mathrm{~b}$ & $82.0 \mathrm{~b}$ & $82.5 \mathrm{~b}$ & $85.0 \mathrm{~b}$ & $81.3 \mathrm{~b}$ \\
\hline T4. Sethoxy dim -165 & V4/V5 & $76.5 \mathrm{c}$ & $82.0 \mathrm{~b}$ & $78.8 \mathrm{~b}$ & $87.5 \mathrm{~b}$ & $92.5 \mathrm{a}$ & $87.5 \mathrm{~b}$ \\
\hline T5. Haloxy fop - 36 & V4/V5 & $88.0 \mathrm{~b}$ & $92.5 \mathrm{a}$ & $93.8 \mathrm{a}$ & $98.3 \mathrm{a}$ & $99.5 \mathrm{a}$ & $100.0 \mathrm{a}$ \\
\hline T6. Haloxy fop -45 & V4/V5 & $97.5 \mathrm{a}$ & $100.0 \mathrm{a}$ & $100.0 \mathrm{a}$ & $98.3 \mathrm{a}$ & $100.0 \mathrm{a}$ & $100.0 \mathrm{a}$ \\
\hline T7. Clethodim -65 & $\mathrm{~V} 7 / \mathrm{V} 8$ & $42.5 \mathrm{e}$ & $68.8 \mathrm{c}$ & $66.3 \mathrm{c}$ & $61.3 \mathrm{~d}$ & $75.0 \mathrm{c}$ & $93.3 \mathrm{a}$ \\
\hline T8. Clethodim - 84 & $\mathrm{~V} 7 / \mathrm{V} 8$ & $50.0 \mathrm{~d}$ & $75.0 \mathrm{c}$ & $76.3 \mathrm{~b}$ & $67.5 \mathrm{c}$ & $83.8 \mathrm{~b}$ & $97.8 \mathrm{a}$ \\
\hline T9. Sethoxy dim - 138 & $\mathrm{~V} 7 / \mathrm{V} 8$ & $12.5 \mathrm{f}$ & $21.3 \mathrm{~d}$ & $18.8 \mathrm{~d}$ & $41.3 \mathrm{e}$ & $46.3 \mathrm{~d}$ & $66.3 \mathrm{c}$ \\
\hline T10. Sethoxy dim -165 & $\mathrm{~V} 7 / \mathrm{V} 8$ & $12.5 \mathrm{f}$ & $21.3 \mathrm{~d}$ & $21.3 \mathrm{~d}$ & $36.3 \mathrm{e}$ & $51.3 \mathrm{~d}$ & $82.5 \mathrm{~b}$ \\
\hline T11. Haloxy fop - 36 & $\mathrm{~V} 7 / \mathrm{V} 8$ & $52.5 \mathrm{~d}$ & $73.8 \mathrm{c}$ & $73.8 \mathrm{~b}$ & $60.0 \mathrm{~d}$ & $80.0 \mathrm{c}$ & $95.8 \mathrm{a}$ \\
\hline T12. Haloxy fop -45 & $\mathrm{~V} 7 / \mathrm{V} 8$ & $47.5 \mathrm{~d}$ & $73.8 \mathrm{c}$ & $73.8 \mathrm{~b}$ & $68.8 \mathrm{c}$ & $88.8 \mathrm{~b}$ & $96.5 \mathrm{a}$ \\
\hline \multicolumn{2}{|c|}{$\begin{array}{l}\text { T13. Check plots without application } \\
\text { T14. Check plots with manual weeding }\end{array}$} & $0.0 \mathrm{~g}$ & $0.0 \mathrm{e}$ & $0.0 \mathrm{e}$ & $0.0 \mathrm{f}$ & $0.0 \mathrm{e}$ & $0.0 \mathrm{~d}$ \\
\hline \multicolumn{2}{|c|}{ T14. Check plots with manual weeding } & $100.0 \mathrm{a}$ & $100.0 \mathrm{a}$ & $100.0 \mathrm{a}$ & $100.0 \mathrm{a}$ & $100.0 \mathrm{a}$ & $100.0 \mathrm{a}$ \\
\hline \multicolumn{2}{|c|}{$\mathrm{F}_{\text {treat }}$} & $220.58 *$ & $140.06^{*}$ & $186.84 *$ & $110.62 *$ & $116.05^{*}$ & $168.23^{*}$ \\
\hline \multicolumn{2}{|c|}{ CV $(\%)$} & 7.74 & 7.87 & 6.92 & 7.99 & 6.74 & 4.78 \\
\hline
\end{tabular}

*F test significant at $1 \% ;{ }^{1}$ Means followed by the same letter in the columns are similar by the Scott-Knott test at $5 \%$ probability; ${ }^{2} \mathrm{SCP}=$ Santa Cruz das Palmeiras, SP, Brazil; ${ }^{3} \mathrm{NMT}=$ Não-Me-Toque, RS, Brazil; CV = coefficient of variation.

Similarly, Costa et al. (2014) found that clethodim applications were efficient on maize hybrid at V5 stage, but unsatisfactory for plants at V8. Deen et al. (2006) evaluated the control of voluntary maize based on combined applications of glyphosate and graminicides and found more efficiency with the use of the herbicide quizalofop-pethyl, followed by clethodim and fenoxaprop-pethyl; the combined application of glyphosate, graminicides, and adjuvants did not affect the herbicide efficacy or soybean tolerance.

The herbicide application, absorption, translocation, and metabolism are factors that affect the expression of symptoms. The metabolism of xenobiotics is related to the cytochrome $\mathrm{P} 450$ enzyme complex and to the enzyme glutathione-Stransferase, mainly to P450 for ACCase inhibitors. Thus, more developed plants may have a more complete and active enzymatic apparatus, allowing them to decompose more active ingredient with less expression of symptoms (CARVALHO et al., 2009; DIAS; CARVALHO; CHRISTOFFOLETI, 2013). Thus, as maize plants develop, they become more capable of decomposing herbicides and, consequently, more tolerant to herbicide application.

Soltani, Shropshire and Sikkema (2006) found satisfactory results with applications of clethodim, fenoxaprop-p-ethyl, fluazifop-p-butyl, and quizalofop-p-ethyl to control volunteer maize plants. Furthermore, some studies found adequate control of glyphosate-resistant volunteer maize for the herbicide haloxyfop applied alone or in combination with glyphosate, 2,4-D, or fluroxypir (COSTA et al, 2014; PETTER et al., 2015).

The soybean crop stand and yield in SCP (Table 3) were higher when the graminicides were applied early, i.e., when the volunteer maize plants were at the V4/V5 stage and the soybean plants had three trifoliate leaves (3T). The early application of graminicides ensured the full crop stand and yield, showing similar values to those of check plots (manual weeding) throughout this experiment. The presence of volunteer maize plants throughout the soybean crop cycle resulted in losses of $84.6 \%$ in crop yield in SCP (Table 3 ).

The soybean plants of the check plots with manual weeding in NMT presented an adequate yield, reaching 4,445.6 $\mathrm{kg} \mathrm{ha}^{-1}$. This yield was also reached only by plants under treatments with clethodim (84 $\mathrm{g} \mathrm{ha}^{-1}$ ) and haloxyfop (36 $\mathrm{g} \mathrm{ha}^{-1}$ ) applied on maize plants at V4/V5, showing correlation between the volunteer maize control and soybean yield. The treatments had no effect on the soybean stand in NMT (Table 3).

Marquardt and Johnson (2013) also found full soybean crop yield when applied clethodim (79 $\mathrm{g} \mathrm{ha}^{-1}$ ), but combined with glyphosate $\left(840 \mathrm{~g} \mathrm{ha}^{-1}\right)$. The selectivity of ACCase inhibitors for soybean crops is known; it is due to enzymatic insensitivity, since dicotyledonous plants have herbicide-insensitive enzyme isoforms (SASAKI; NAGANO, 2004; LÓPEZ-OVEJERO et al., 2016b). Therefore, losses are due to competition with volunteer plants. According to Beckett and Stoller (1988), soybean yields were $2 \%, 6 \%, 12 \%, 19 \%$, and $27 \%$ lower due to the presence of volunteer maize plants when herbicides were applied at 2, 4, 6, 8, and 10 weeks after the soybean emergence, respectively. The use of graminicides is an alternative for the control of glyphosate-resistant weed biotypes, with emphasis on Lolium multiflorum and Digitaria insularis (MACIEL et al., 2013, COSTA et al., 2014). 
Table 3. Soybean crop stand and yield $\left(\mathrm{kg} \mathrm{ha}^{-1}\right)$ in two areas with infestation of glyphosate-resistant volunteer maize plants subjected to chemical control when the soybean plants were at the $3 \mathrm{~T}$ (three trifoliate leaves) or 6T (6 trifoliate leaves) stages.

\begin{tabular}{|c|c|c|c|c|c|}
\hline \multirow{2}{*}{ Treatments $\left(\mathrm{g} \mathrm{ha}^{-1}\right)$} & \multirow{2}{*}{$\begin{array}{l}\text { Soybean stage at } \\
\text { application }\end{array}$} & \multicolumn{2}{|c|}{$\mathrm{SCP}^{2}$} & \multicolumn{2}{|c|}{$\mathrm{NMT}^{3}$} \\
\hline & & Stand & Yield $\mathrm{kg} \mathrm{ha}^{-1}$ & Stand & Yield $\mathrm{kg} \mathrm{ha}^{-1}$ \\
\hline T1. Clethodim -65 & $3 \mathrm{~T}$ & $91 \mathrm{a}$ & $3529.1 \mathrm{a}$ & 102 & $4270.7 \mathrm{~b}$ \\
\hline T2. Clethodim -84 & $3 \mathrm{~T}$ & $95 \mathrm{a}$ & $3571.4 \mathrm{a}$ & 117 & $4661.2 \mathrm{a}$ \\
\hline T3. Sethoxy dim -138 & $3 \mathrm{~T}$ & $101 \mathrm{a}$ & $3448.2 \mathrm{a}$ & 116 & $4098.5 \mathrm{~b}$ \\
\hline T4. Sethoxydim -165 & $3 \mathrm{~T}$ & $100 \mathrm{a}$ & $3160.6 \mathrm{a}$ & 114 & $4167.9 \mathrm{~b}$ \\
\hline T5. Haloxy fop -36 & $3 \mathrm{~T}$ & $93 \mathrm{a}$ & $3765.2 \mathrm{a}$ & 115 & $4684.6 \mathrm{a}$ \\
\hline T6. Haloxy fop -45 & $3 \mathrm{~T}$ & $100 \mathrm{a}$ & $3424.3 \mathrm{a}$ & 109 & $4306.2 \mathrm{~b}$ \\
\hline T7. Clethodim -65 & $6 \mathrm{~T}$ & $87 \mathrm{~b}$ & $1523.3 \mathrm{~b}$ & 95 & $3494.5 \mathrm{c}$ \\
\hline T8. Clethodim -84 & $6 \mathrm{~T}$ & $82 \mathrm{~b}$ & $1974.3 \mathrm{~b}$ & 103 & $3926.3 \mathrm{~b}$ \\
\hline T9. Sethoxydim -138 & $6 \mathrm{~T}$ & $84 \mathrm{~b}$ & $600.3 \mathrm{~d}$ & 105 & $3295.1 \mathrm{c}$ \\
\hline T10. Sethoxy dim -165 & $6 \mathrm{~T}$ & $70 \mathrm{c}$ & $1159.6 \mathrm{c}$ & 98 & $3383.7 \mathrm{c}$ \\
\hline T11. Haloxy fop - 36 & $6 \mathrm{~T}$ & $74 \mathrm{c}$ & $1614.8 \mathrm{~b}$ & 111 & $3508.6 \mathrm{c}$ \\
\hline T12. Haloxy fop -45 & $6 \mathrm{~T}$ & $85 \mathrm{~b}$ & $2089.6 \mathrm{~b}$ & 107 & $3443.0 \mathrm{c}$ \\
\hline \multicolumn{2}{|c|}{ T13. Check plots without application } & $86 \mathrm{~b}$ & $500.5 \mathrm{~d}$ & 100 & $1079.7 \mathrm{~d}$ \\
\hline \multicolumn{2}{|c|}{ T14. Check plots with manual weeding } & $105 \mathrm{a}$ & $3673.9 \mathrm{a}$ & 106 & $4445.6 \mathrm{a}$ \\
\hline \multicolumn{2}{|c|}{$\mathrm{F}_{\text {Treat }}$} & $8.837^{* *}$ & $33.799 * *$ & $1.437^{\mathrm{NS}}$ & $27.728 * *$ \\
\hline \multicolumn{2}{|l|}{$\mathrm{CV}(\%)$} & 7.74 & 17.06 & 10.76 & 9.18 \\
\hline
\end{tabular}

*F test significant at $1 \% ;{ }^{\mathrm{NS}}=\mathrm{F}$ test not significant; ${ }^{1}$ Means followed by the same letter in the columns are similar by the Scott-Knott test at $5 \%$ probability; ${ }^{2} \mathrm{SCP}=$ Santa Cruz das Palmeiras, SP, Brazil; ${ }^{3} \mathrm{NMT}=$ Não-Me-Toque, RS, Brazil; CV $=$ coefficient of variation.

López-Ovejero et al. (2016a) evaluated the control of glyphosate-resistant maize from ear fragments using clethodim and found that soybean yield was maintained when using a single application of clethodim $\left(108 \mathrm{~g} \mathrm{ha}^{-1}\right)$ on the soybean plants at the stage of six trifoliate leaves (6T) or two applications of clethodim (108 $\mathrm{g} \mathrm{ha}^{-1}$ and $\left.84 \mathrm{~g} \mathrm{ha}^{-1}\right)$ at plants at $3 \mathrm{~T}$ and $6 \mathrm{~T}$ stages, respectively. Thus, different from infestation of maize plants from ears, delaying the control of maize plants from grains of previous harvests hinders soybean yield. This is explained by the uneven and, possibly, slower germination of grains in ears and by the competition between the plants.

Therefore, control of volunteer maize plants in soybean crops should begin during the maize crop cycle, with emphasis on the maize harvesting (LÓPEZ-OVEJERO et al., 2016a). According to Puzzi (1986), delaying mechanical harvesting after maize maturation causes a decrease in grain water content and, consequently, significant loss increases. Souza et al. (2006) found a total loss of 9\% during the mechanized maize harvesting process, which may have been favored by the delay in the harvest. The harvest time in the present work was at approximately 30 days after plant maturation.

The results indicate that the control of glyphosate-resistant volunteer maize should be carried out early, when the maize plants are at the V4/V5 stage and soybean plants have three trifoliate leaves, mainly when maize plants are from grains lost during the harvesting process. Thus, the adoption of the herbicides clethodim and haloxyfop is recommended for their consistent effectiveness.

\section{CONCLUSIONS}

Early application of graminicides on glyphosate-resistant maize plants results in a higher control level. The herbicides clethodim and haloxyfop are adequate options for the control of glyphosate-resistant volunteer maize, mainly when they are applied on maize plants at the V4/V5 stage. The satisfactory effectiveness of these herbicides can ensure an adequate soybean stand and yield.

\section{REFERENCES}

ARTUZI, J. P.; CONTIERO, R. L. Herbicidas aplicados na soja e produtividade do milho em sucessão. Pesquisa Agropecuária Brasileira, v. 41, n. 7, p. 1119-1123, 2006.

BECKETT, T. H.; STOLLER, E. W. Volunteer maize (Zea mays) interference in soybeans (Glycine max). Weed Science, v. 35, n. 2, p. 159-166, 1988.

CARVALHO, S. J. P. et al. Herbicide selectivity by differential metabolism: consideration for reducing crop damages. Scientia Agricola, v. 66, n. 1, p. 136$142,2009$.

CHAHAL, P. S. et al. Efficacy of pre-emergence and post emergence soybean herbicides for control of glufosinate-, glyphosate-, and imidazolinoneresistant volunteer maize. Journal of Agricultural Science, v. 6, n. 8, p. 431-443, 2014. 
CLEWIS, S. B. et al. Glufosinate resistant maize interference in glufosinate resistant cotton. Weed Technology, v. 22, n. 2, p. 211-216, 2008.

COMPANHIA

NACIONAL

DE

ABASTECIMENTO - CONAB. Acompanhamento da safra brasileira: grãos, safra 2017/2018. Brasília: CONAB, 2018. 125 p.

COSTA, N. V. et al. Glyphosate tolerant volunteer maize control at two development stages. Planta Daninha, v. 32, n. 4, p. 675-682, 2014.

DEEN, W. et al. Control of volunteer glyphosateresistant maize (Zea mays) in glyphosate-resistant soybean (Glycine max). Weed Technology, v. 20, n. 1, p. 261-266, 2006.

DIAS, A. C. R.; CARVALHO, S. J. P.; CHRISTOFFOLETI, P. J. Fenologia da trapoeraba como indicador para tolerância ao herbicida glyphosate. Planta Daninha, v. 31, n. 1, p. 185-191, 2013.

FRANS, R. et al. Experimental design and techniques for measuring and analyzing plant responses to weed control practices. In: CAMPER, N.D. (Eds.). Research methods in weed science. Champaign: Southern Weed Science Society, 1986. 3. ed. cap. 2, p.29-46.

LÓPEZ-OVEJERO, R. F. et al. Interferência e controle de milho voluntário tolerante ao glifosato na cultura da soja. Pesquisa Agropecuária Brasileira, v. 51, n. 4, p. 340-347, 2016 a.

LÓPEZ-OVEJERO, R.F. et al. Resistência de plantas daninhas aos herbicidas inibidores da ACCase (Grupo A). In: CHRISTOFFOLETI, P.J.; NICOLAI, M. (Coord.). Aspectos de resistência de plantas daninhas a herbicidas. Piracicaba: ESALQ, 2016 b. 4. ed., cap.5, p. 77-97.

MACIEL, C. D. G. et al. Eficácia do herbicida haloxyfop $\mathrm{R}$ (GR-142) isolado e associado ao 2,4D no controle de híbridos de milho $R R \AA$ voluntário.

Revista Brasileira de Herbicidas, v. 12, n. 2, p. 112 $-123,2013$.

MARCA, V. et al. Chemical control of glyphosateresistant volunteer maize. Revista Brasileira de Herbicidas, v. 14, n. 2, p. 103-110, 2015.

MARQUARDT, P.; KRUPKE, C.; JOHNSON, W. G. Competition of transgenic volunteer maize with soybean and the effect on western maize rootworm emergence. Weed Science, v. 60, n. 2, p. 193-198, 2012.
MARQUARDT, P.; JOHNSON, W. G. Influence of clethodim application timing on control of volunteer maize in soybean. Weed Technology, v. 27, n. 4, p. 645-648, 2013.

PETTER, F. A. et al. Volunteer RR ${ }^{\circledR}$ maize management in roundup ready ${ }^{\circledR}$ soybean-maize succession system. Planta Daninha, v. 33, n. 1, p. 119-128, 2015.

PUZZI, D. Abastecimento e armazenagem de grãos. 1. ed. Campinas, SP: Instituto Campineiro de Ensino Agrícola, 1985. 603p.

SASAKI, Y.; NAGANO, Y. Plant acetyl-CoA carboxylase: structure, biosynthesis, regulation, and gene manipulation for plant breeding. Bioscience, Biotechnology and Biochemistry, v. 68 , n. 6 , p. 1175-1184, 2004.

SCOTT, A. J.; KNOTT, M. A. Cluster analysis method for grouping means in the analysis of variance. Biometrics, v. 30, n. 2, p. 507-512, 1974.

SOCIEDADE BRASILEIRA DA CIÊNCIA DAS PLANTAS DANINHAS - SBCPD. Procedimentos para instalação, avaliação e análise de experimentos com herbicidas. 1. ed. Londrina, PR: SBCPD, 1995. 42p.

SOLTANI, N.; SHORPSHIRE, C.; SIKKEMA, P. $\mathrm{H}$. Control of volunteer glyphosate-tolerant maize (Zea mays) in glyphosate-tolerant soybean (Glycine $\max )$. Crop Protection, v. 25, n. 2, p. 178-181, 2006.

SOUZA, C. M. A. et al. Perdas na colheita mecanizada de milho em agricultura familiar da Zona da Mata mineira. Revista Brasileira de Milho e Sorgo, v. 5, n. 2, p. 280-290, 2006.

STECKEL, L. E.; THOMPSON, M. A.; HAYES, R. M. Herbicide options for controlling glyphosatetolerant maize in a maize replant situation. Weed Technology, v. 23, n. 2, p. 243-246, 2009.

THOMAS, W. E. et al. Glyphosate resistant maize interference in glyphosate-resistant cotton. Weed Technology, v. 21, n. 2, p. 372-377, 2007. 